\title{
Dark chocolate administration improves working memory in students
}

\author{
Nawanto Agung Prastowo*, Samuel Kristanto*, and Poppy Kristina Sasmita**
}

ABSTRACT

\section{BACKGROUND}

Flavonoids have positive effects on health, including the nervous system. High flavonoid content can be found in chocolate, especially dark chocolate. Verbal working memory is important for reasoning, language comprehension, planning, and spatial processing. The purpose of this study was to evaluate the effect of a single dose of dark and white chocolate administration on verbal working memory in medical students.

\section{METHODS}

A study of experimental pre-post test design with controls was conducted on 60 students. These were simply randomized into two groups: the first group was supplemented with white chocolate as control, and the second group received dark chocolate, at an identical single dose of $100 \mathrm{~g}$. Working memory was measured with the digit span forwards (DSF) and the digit span backwards (DSB) tests, before, at 1 hour, and at 3 hours after intervention. Independent $t$ and Mann-Whitney tests were used for data analysis.

\section{RESULTS}

Scores for DSF and DSB in control and treatment groups were similar at baseline. At 1 hour after dark and white chocolate administration, DSF and DSB scores were not significantly different between the two groups $(\mathrm{p}=0.832 ; \mathrm{p}=0.683$ ). Supplementation of dark chocolate at 3 hours after intervention significantly increased DSB scores compared to white chocolate $(\mathrm{p}=0.041)$, but DSF scores were not significantly different between the two groups $(\mathrm{p}=0.204)$.

\section{CONCLUSIONS}

Dark chocolate as a single dose is capable of improving verbal working memory in students, 3 hours after its consumption. Since cocoa contains multiple bioactive compounds, one approach might be to examine the neurocognitive effects of combinations of potential functional ingredients.

Keywords: Antioxidant, flavonoid, dark chocolate, working memory, students
*Department of Physiology,

Faculty of Medicine,

Atma Jaya University

**Department of Anatomy,

Faculty of Medicine,

Atma Jaya University

\section{Correspondence:}

Nawanto Agung Prastowo

Department of Physiology,

Faculty of Medicine,

Atma Jaya University

Jalan Pluit Raya no 2,

Jakarta Utara, Jakarta 14444

Email: nawanto2005@yahoo.co.id

Handphone: 081317477849

Faksimili: 021-660-6123

Univ Med 2015;34:229-36

DOI: 10.18051/UnivMed.2016.v35.229-236

pISSN: 1907-3062 / eISSN: 2407-2230

This open access article is distributed under a Creative Commons Attribution-Non Commercial-Share Alike 4.0 International License 


\section{Pemberian coklat hitam memperbaiki memori kerja pada mahasiswa}

\section{ABSTRAK}

\section{LATAR BELAKANG}

Flavonoid memiliki efek positif terhadap kesehatan termasuk sistem saraf. Kandungan flavonoid tinggi dapat ditemukan pada coklat terutama coklat hitam. Memori kerja penting untuk proses penalaran, pemahaman bahasa, perencanaan, dan pemahaman spasial. Tujuan penelitian ini untuk menilai pengaruh pemberian coklat hitam dan coklat putih dosis tunggal terhadap memori kerja pada mahasiswa.

\section{METODE}

Penelitian eksperimental pre-post test design menggunakan kontrol dilakukan pada 60 mahasiswa. Mereka secara acak sederhana dibagi menjadi dua kelompok, yaitu kelompok pertama diberikan coklat putih sebagai kontrol dan kelompok kedua coklat hitam dengan dosis tunggal yang sama sebanyak $100 \mathrm{gr}$. Memori kerja diuji dengan digit span test (DST) forward (DSF) dan backward (DSB) sebelum, 1 dan 3 jam setelah intervensi. Uji statistik yang digunakan adalah uji t-independen dan Mann-Whitney untuk menguji perbandingan skor DST antara kelompok.

\section{HASIL}

Tidak terdapat perbedaan bermakna skor DSF dan DSB antara kelompok kontrol dan perlakuan pada tahap awal penelitian. Setelah 1 jam baik pemberian coklat hitam maupun coklat putih tidak menunjukkan perbedaan yang bermakna skor DSF dan DSB antara kedua kelompok perlakuan ( $p=0,832 ; p=0,683)$. Pemberian coklat hitam setelah 3 jam, ternyata skor DSB lebih tinggi secara bermakna dibandingkan coklat putih $(p=0,041)$, dan skor DSF tidak menunjukkan perbedaan yang bermakna $(p=0,204)$ antara kedua kelompok.

\section{KESIMPULAN}

Pemberian coklat hitam dengan dosis tunggal setelah 3 jam mampu meningkatkan memori kerja pada mahasiswa. Coklat hitam bersifat antioksidan karena mengandung flavanols bermanfaat untuk meningkat fungsi nerokognitif pada mahasiswa.

Kata kunci: Antioksidan, flavonoid, coklat hitam, memori kerja, mahasiswa

\section{INTRODUCTION}

Chocolate is produced from cacao (Theobroma cacao L.) beans and contains flavanols, a class of flavonoids with considerable antioxidant activity, being thus of benefit to human health. ${ }^{(1)}$ In comparison with white chocolate, the antioxidant content of dark chocolate is higher, as a result of fermentation, without the addition of other ingredients, such as powdered milk, sugar, and fat. ${ }^{(2)}$ Therefore dark chocolate has a bitter taste and is thus less favored.
There are many studies on the effect of flavanols on cognitive function, the majority of which showed enhanced cognitive function after administration of flavanols. However, there are few studies comparing the effects of administration of dark and white chocolate on cognitive function. One study comparing the effects of acute administration of dark and white chocolate was conducted by Field et al. ${ }^{(3)}$ using a crossover design, in which dark chocolate with a content of $720 \mathrm{mg}$ cocoa flavanols was given, followed by administration of white chocolate, with an interval of one week between the two 
interventions. The results showed that dark chocolate enhanced cognitive function to a higher extent than did white chocolate.

Working memory plays an important role in cognitive function, particularly in reasoning, language comprehension, planning, and spatial processing. ${ }^{(4)}$ Working memory is a combination of attention, concentration, and short-term memory, and refers to the capacity for temporary retention and manipulation of information. ${ }^{(5)}$ Working memory is influenced by sleep quality, ${ }^{(6)}$ diet, ${ }^{(7)}$ and age ${ }^{(8)}$ Several disorders, particularly those affecting the brain, such as Alzheimer's disease, stroke, head injury, and brain tumors, result in working memory dysfunction. ${ }^{(5)}$

The digit span test (DST) is a test for measuring working memory function, and is frequently used because of its simplicity and high reliability of up to $0.9 .^{(9)}$ The DST consists of a sequence of digits that must be memorized and verbally repeated by the test subject. DST results are consistently good in normal elderly, ${ }^{(10)}$ in elderly with cognitive dysfunction, ${ }^{(11)}$ and also in children. ${ }^{(12)}$

The objective of this study was to evaluate the effect of administration of dark and white chocolate on working memory in students, and differs from previous studies in the use of a parallel group design.

\section{METHODS}

\section{Design of the study}

This was an experimental study of preposttest nonblinded design with controls and conducted in Jakarta from January to April 2015.

\section{Subjects}

The subjects were preclinical medical students $\left(1^{\text {st }}-4^{\text {th }}\right.$ year $)$ who participated in this study and met the inclusion criteria, i.e. male and female students, in the preclinical years, healthy, of normal hearing, and agreeing to participate in the study up to its completion. The exclusion criteria were hypersensitivity to chocolate, insomnia, smoking, drinking, and history of head injury within the last 6 months. The drop-out criteria were consumption of flavonoid-containing foods or drinks 24 hours before the study, and in the 3-hour waiting period before the DST. Informed consent was obtained in written form. Information on the effect of type of chocolate on DST results was not given to the prospective subjects to avoid bias.

Sample size was calculated with the formula for comparative numerical analysis of two independent groups:

$$
\mathrm{N}=2\left\{\frac{(\mathrm{Z} \alpha+\mathrm{Z} \beta) \cdot \mathrm{S}}{\left(\mathrm{X}_{1}-\mathrm{X}_{2}\right)}\right\}^{2}
$$

where Zá $(5 \%)=1.96$, Zâ $(85 \%)=1.282, \mathrm{~S}=0.3$, $\mathrm{X}_{1}-\mathrm{X}_{2}=0.25$. $^{(13)}$ Anticipating a drop out rate of $10 \%$, the number of subjects for each group was 30 , so that the total number of subjects was 60 .

\section{Intervention}

Subjects were allocated by simple randomization to 2 groups, i.e. the control group and the treatment group, each group consisting of 15 females and 15 males. The control group and the treatment group received white and dark chocolate bars, respectively, at a single oral dose of $100 \mathrm{~g}$, which is the standard dose for determining chocolate contents. ${ }^{(14,15)}$ The flavonoid content of $100 \mathrm{~g}$ of dark chocolate is $\approx 28.3 \mathrm{mg}$, and that of $100 \mathrm{~g}$ of white chocolate is $\approx 7.7 \mathrm{mg} .{ }^{(15)}$ The outer wrappers were removed before the bars were given to the subjects, so that it was not apparent what type of chocolate was to be consumed. However, the subjects could still distinguish the type of chocolate by its color, since the white chocolate was of lighter color, whereas the dark chocolate was of darker color.

\section{Measurement of working memory}

Measurement of working memory was performed using the DST. The subjects underwent a 24-hour wash-out period before the DST test, to remove flavonoids from plasma, by abstaining from consumption of flavonoidcontaining foods and drinks. After the wash-out 
period, both groups underwent the DST test, consisting of the DST forwards (DSF) and DST backwards (DSB). After completing the first DST tests (DSF-pre and DSB-pre), the subjects underwent the second and third DST tests, i.e. at 1 hour (DSF1 \& DSB1) and 3 hours (DSF3 and DSB3) after chocolate consumption. While waiting for the DST, the subjects were allowed to perform their regular activities, but were not permitted to consume foods or drinks other than those provided by the investigators.

In the DSF test, the subjects have to verbally repeat a sequence of digits presented by the investigators in their exact order, whereas in the DSB test the subjects have to repeat the digits in reverse order. The test is started by the investigators calling out a 4-digit number in random order (e.g. 3729) at a rate of 1 digit per second, then the subjects verbally repeating the digits in their given order. If the subjects has repeated the digits in the correct order, the list of digits is increased by 1 digit. If the subjects are unable to repeat the digits in their correct order, the test is followed by the DSB test. The subjects have two opportunities to listen to and repeat the series of digits. The test is discontinued if the subjects on the two occasions are unable to repeat the digits in their correct order. The DST score is the longest list of digits that has been repeated correctly. If the subjects can repeat a 9-digit number, the DST score is 9. ${ }^{(9,16)}$ In the present study there were 3 sets of digit lists for the DSF and 3 sets for the DSB, each set consisting of digit lists in different order.

\section{Statistical analysis}

The Shapiro-Wilk test was used to test for the normality of the data distribution. The independent t-test or Mann-Whitney test was used to find differences in DST scores between the two groups. The level of significance was set at $\mathrm{p}<0.05$ with a confidence interval of $95 \%$.

\section{Ethical clearance}

Ethical clearance was obtained from the Research Ethics Commission, Faculty of Medicine, Atma Jaya University, Jakarta. Signed written informed consent was obtained from all subjects. The identity of the subjects was kept secret and was used only for research purposes.

\section{RESULTS}

A total of 84 students agreed to participate in the study by filling in an agreement form. A total of 16 students withdrew from the study because of academic reasons. Randomization was performed on 68 subjects, consisting of 36

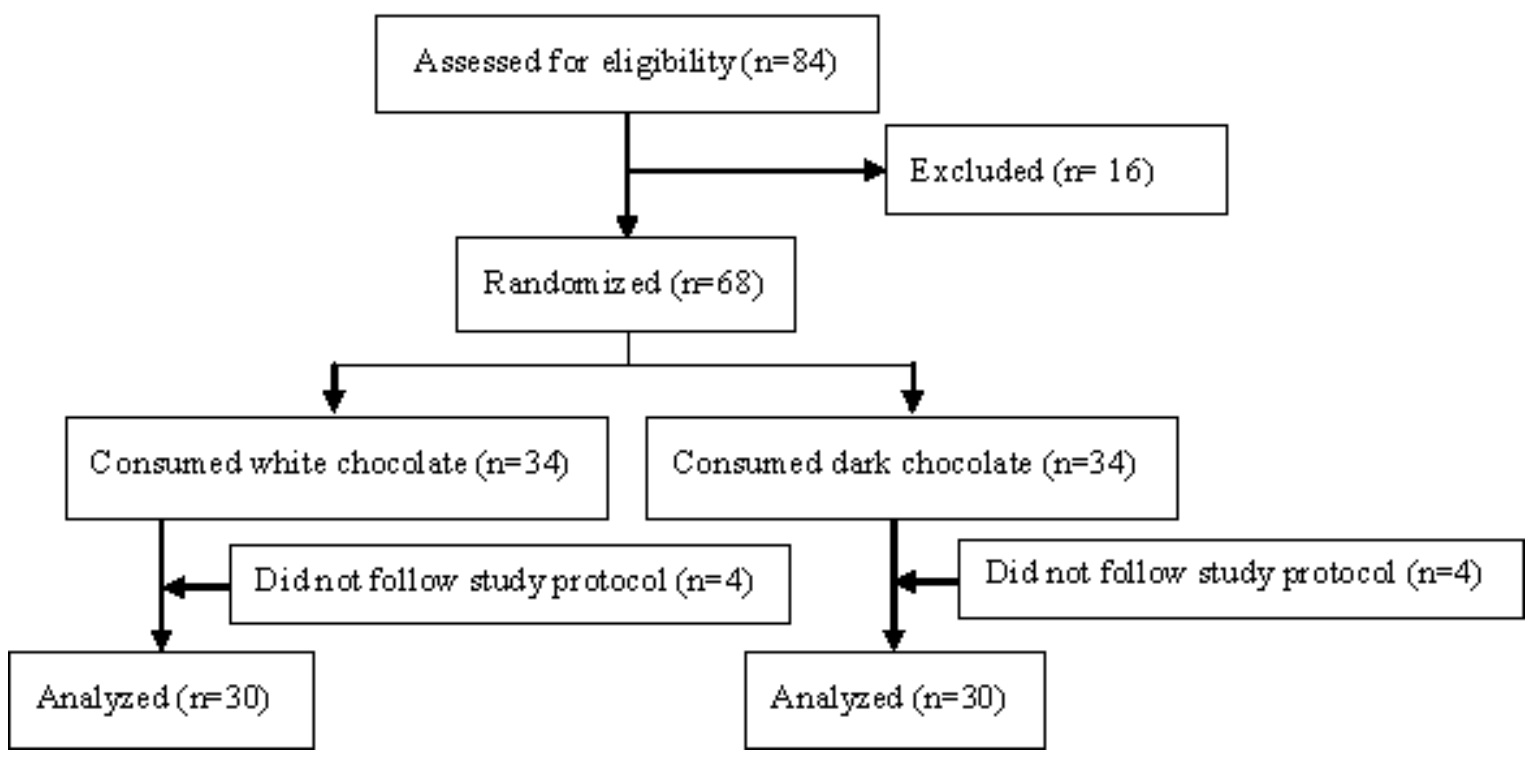

Figure 1. Flowchart of subject participation 
Table 1. Mean age and DST scores of the control and treatment groups at baseline

\begin{tabular}{lccc}
\hline & Control & Treatment & P value \\
\hline Age (years) & $19.9 \pm 1.1$ & $19.3 \pm 1.0$ & 0.062 \\
DSF & $6.6 \pm 2.0$ & $6.9 \pm 2.3$ & 0.591 \\
DSB & $4.7 \pm 1.7$ & $4.7 \pm 2.6$ & 0.954 \\
\hline
\end{tabular}

DSF=Digit span forwards; DSB=Digit span backwards

females and 32 males, to determine the type of intervention. In the randomization process the female subjects were separated from the males, to ensure that each intervention group received an identical number of female and males. On completion of the DST tests, the results from 8 subjects ( 2 males and 6 females) were considered invalid, since they had knowledge of the differing effects of the type of chocolate on the DST test results (Figure 1). A total of 60 subjects met the requirements and participated in the study up to its completion.

Except for the baseline DSF and DSB scores, all DST scores were non-normally distributed $(\mathrm{p}>0.05)$, so that a non-parametric test was performed. Table 1 presents the characteristics and DST measurement results in both groups at baseline. The independent t-test showed no significant differences for age, DSF scores and DSB scores between both groups $(\mathrm{p}=0.062 ; \mathrm{p}=0.591 ; \mathrm{p}=0.954)$.

Table 2. Differences in DSF and DSB scores of the control and treatment groups after intervention

\begin{tabular}{lccc}
\hline & Control & Treatment & p-value \\
\hline DSF1 & $6.9 \pm 1.9$ & $7.0 \pm 2.0$ & 0.842 \\
DSF3 & $7.2 \pm 2.0$ & $7.9 \pm 2.1$ & 0.204 \\
DSB1 & $5.0 \pm 1.6$ & $4.8 \pm 2.2$ & 0.683 \\
DSB3 & $4.9 \pm 1.6$ & $6.0 \pm 2.7$ & $0.041 *$ \\
\hline
\end{tabular}

*Mann-Whitney test; DSF1 : Digit span forwards 1 hour after intervention; DSF3 : digit span forwards 3 hours after intervention; DSB1 : Digit span backwards 1 hour after intervention; DSB3 : Digit span backwards 3 hours after intervention
At 1 hour and 3 hours after intervention, mean DSF scores were not significantly different between the two intervention groups $(\mathrm{p}=0.842$; $\mathrm{p}=0.204)$. However, at 3 hours after intervention, the DSB scores were significantly different between the two intervention groups $(\mathrm{p}=0.041)$ (Table 2). Administration of dark chocolate resulted in significantly higher DSB scores at 3 hours after intervention than did administration of white chocolate.

\section{DISCUSSION}

The present study demonstrates that administration of a single dose of dark chocolate significantly improved working memory of medical students after 3 hours of intervention to a higher extent than did administration of white chocolate. These results are similar to those of the study of Field et al. ${ }^{(3)}$ who also compared the effects of acute administration of dark and white chocolate. In the study of Field et al. the cognitive function of the treatment group was better than that of the control group. The dose of chocolate in the present study was greater than that used in the study of Field (100g vs $35 \mathrm{~g}$ ). For cognitive testing, Field et al. ${ }^{(3)}$ used visual spatial working memory, whereas we used DST. The effect of flavanols on cognitive function depends on the dose or concentration. The study by Scholey et al. ${ }^{(17)}$ used cocoa flavanols (CF) in differing concentrations $(46 \mathrm{mg}, 520 \mathrm{mg}$, and $994 \mathrm{mg}$ ). Their results showed an increase in cognitive ability and mood in subjects receiving drinks containing $\mathrm{CF}$ at concentrations of 520 $\mathrm{mg}$ and $994 \mathrm{mg}$. The study by Mastroiacovo et al. ${ }^{(18)}$ also used drinks containing $\mathrm{CF}$ at similar concentrations (48 mg, $520 \mathrm{mg}$, and $993 \mathrm{mg}$ ). The results showed that subjects receiving $\mathrm{CF}$ at concentrations of $520 \mathrm{mg}$ and $993 \mathrm{mg}$ experienced improvement in the cognitive aspects. In our study, the subjects were given dark and white chocolate at a dose of $100 \mathrm{~g}$. The flavanol content of dark chocolate is around $450 \mathrm{mg}$ per $100 \mathrm{~g}$, whereas that of white chocolate is approximately one-fourth that of 
dark chocolate, ${ }^{(15)}$ since white chocolate contains more additives to remove the bitter taste and improve appearance. ${ }^{(2)}$ These additives may reduce the antioxidant content of white chocolate, thus reducing the effectiveness of chocolate on cognitive function. ${ }^{(19)}$

Dark chocolate has antioxidant properties because it contains flavanols, which occur as catechin and epicatechin monomers. ${ }^{(19-21)}$ Dark chocolate is also neuroprotective and neurogenetic. Flavanols are lipophilic and can therefore penetrate the blood brain barrier and affect brain function. ${ }^{(1,2)}$ In addition to their antioxidant effect, the neuroprotective and neurogenetic mechanisms of flavanols may occur through the interaction of flavanols with the intracellular signalling pathways, such as the regulation of mitogen-activated protein kinase (MAPK) ${ }^{(2)}$, oxidative stress signalling pathways (e.g. NF-KB), and expression of inflammatory genes (IL-1 $\beta, \mathrm{TNF} \alpha)^{(1,22)}$

The flavonoids used in our study and in previous studies originated from a variety of sources. The study by Nurk et al. (7) used grapes, tea, and chocolate, whereas Fournier et al. ${ }^{(23)}$ used soy milk and an isoflavone supplement as flavonoid sources. In the present study we used chocolate as flavonoid source, considering that chocolate may be more popular and favored by younger subjects. In addition, we considered the bar form to be more practical for provision and presentation in comparison with fresh fruit, drinks or powders.

In the present study, the DST scores at 1 hour after chocolate consumption did not increase significantly. This may have been associated with the peak plasma concentration. The peak plasma concentration of polyphenols is usually reached within 2-3 hours after consumption. ${ }^{(17,19)}$ Flavonoids reach a peak plasma concentration within an identical period, so that their effects can be seen after 2-3 hours. Therefore in the period of 1 hour after consumption the flavonoid plasma concentration may not have been sufficiently high to yield clinically significant effects.
The digit span test (DST) is frequently used in neuropsychology and has been proven to effectively measure cognitive function. The test may be performed as a single test or as part of a method comprising several tests. The DST may be used in children ${ }^{(11)}$ and in the elderly, both in healthy elderly or in elderly with cognitive dysfunction. ${ }^{(12)}$ In the elderly, DST is more acceptable than the Mini Mental State Evaluation (MMSE), ${ }^{(12)}$ while in healthy young persons, MMSE is apparently too simple so that the test results may not show any differences.

Working memory is a combination of attention, concentration, and short-term memory that is important for processing and manipulating information that must be retained temporarily. ${ }^{(15)}$ This capacity is important to medical students in following the educational process, especially in receiving instructions from tutors or instructors, as well as in listening to patients at anamnesis. A good working memory may help medical students to improve their ability to diagnose a problem or disease, and to decide on the measures associated with their study or patients.

The present study has several limitations that may have influenced the results. First, no true blinding could be performed, since the color of the chocolate was visible to the subjects after the removal of the wrappings. The investigators were unable to provide chocolate bars of identical color but of different type. However, blinding could still be maintained, because the subjects had no knowledge of the effects of chocolate type on verbal working memory. The subjects of this study were not informed on the effects of chocolate type on verbal working memory. Second, no homogenization of the subjects was performed on the basis of academic achievement, which is an indicator of cognitive function that may affect working memory and DST scores. We propose to conduct further investigations on the effect of chocolate on cognitive facilitation, in addition to substantiation of functional brain changes associated with the components of cocoa. 


\section{CONCLUSIONS}

Dark chocolate as a single dose is capable of improving verbal working memory in students, at 3 hours after its consumption. Since cocoa contains multiple bioactive compounds, one approach might be to examine the neurocognitive effects of combinations of potential functional ingredients

\section{CONFLICTS OF INTEREST}

This study was not associated with any parties, both financially and non-financially. The cost of the whole study was borne by the investigators themselves without any support of sponsors. The results of this study are solely intended for scientific advancement and not to provide commercial benefits to businesses or certain brands of chocolate.

\section{ACKNOWLEDGEMENTS}

The investigators thank the students of the Faculty of Medicine, Atma Jaya University, who agreed to become study subjects. We also thank Dr. Jimmy Barus, SpS for useful input for correction of the manuscript.

\section{REFERENCES}

1. Rendeiro C, Guerreiro JDT, Williams CM, et al. Flavonoids as modulators of memory and learning: molecular interactions resulting in behavioural effects. Proc Nutr Soc 2012;71:24662.

2. McShea A, Ramiro-Puig E, Munro SB, et al. Clinical benefit and preservation of flavonols in dark chocolate manufacturing. Nutr Rev 2008; 66:630-41.

3. Field DT, Williams CM, Butler LT. Consumption of cocoa flavanols results in an acute improvement in visual and cognitive functions. Physiol Behav 2011;103:255-60.

4. D'Esposito M. From cognitive to neural models of working memory. Phil Trans R Soc B 2007;362:761-72.

5. Budson AE, Price BH. Memory dysfunction. $\mathrm{N}$ Engl J Med 2005;352:692-9.
6. Alhola P, Polo-Kantola P. Sleep deprivation: impact on cognitive performance. Neuropsychiatr Dis Treat 2007;3:553-67.

7. Nurk E, Refsum H, Drevon CA, et al. Intake of flavonoid-rich wine, tea, and chocolate by elderly men and women is associated with better cognitive test performance. J Nutr 2009;139:1207.

8. Barak O, Tsodyks M. Working models of working memory. Neurobiol 2014;25:20-4.

9. Groth-Marnat G, Baker S. Digit span as a measure of everyday attention: a study of ecological validity. Percept Mot Skill 2003;97: 1209-18.

10. Choi HJ, Lee DY, Seo EH, et al. A normative study of the digit span in an educationally diverse elderly population. Psychiatr Investig 2014;11: 39-43

11. Leung JLM, Lee GTH, Lam YH, et al. The use of the Digit Span Test in screening for cognitive impairment in acute medical inpatients. Int Psychogeriatr 2011;23:1569-74.

12. Rosenthal EN, Riccio CA, Gsanger KM, et al. Digit span components as predictors of attention problems and executive functioning in children. Arch Clin Neuropsychol 2006;21:131-9.

13. Sastroasmoro S, Ismail S. Dasar-dasar metodologi penelitian klinis. Edisi 4. Sagung Seto, Jakarta. 2011

14. Grassi D, Lippi C, Necozione S, et al. Shortterm administration of dark chococolate is followed by a significant increase in insulin sensitivity and decrease in blood pressure in healthy persons. Am J Clin Nutr. 2005;81:6114.

15. Meng CC, Jalil AMM, Ismail A. Phenolic and theobromine contents of commercial dark, milk and white chocolates on the Malaysian market. Molecules 2009;14:200-9.

16. Conway ARA, Kane MJ, Bunting MF, et al. Working memory span tasks: a methodological review and user's guide. Psychonom Bull Rev 2005;12:769-86.

17. Scholey AB, French SJ, Morris PJ, et al. Consumption of cocoa flavanols results in acute improvements in mood and cognitive performance during sustained mental effort. J Psychopharmacol 2010;24:1505-14.

18. Mastroiacovo D, Kwik-Uribe C, Grassi D, et al. Cocoa flavanol consumption improves cognitive function, blood pressure control, and metabolic profile in elderly subjects: the Cocoa, Cognition, and Aging (CoCoA) Study-a randomized controlled trial. Am J Clin Nutr 2015;101:53848. 
19. Corti R, Flammer AJ, Hollenberg NK, et al. Cocoa and cardiovascular health Circulation 2009;119:1433-41.

20. Agarwal SK. Dark chocolate: a therapeutic food. Med Sci 2013;5:13-5.

21. Wan Y, Vinson JA, Etherton TD, et al. Effects of cocoa powder and dark chocolate on LDL oxidative susceptibility and prostaglandin concentrations in humans. Am J Clin Nutr 2001; 74:596-602.
22. Williams RJ, Spencer JPE. Flavonoids, cognition, and dementia: actions, mechanisms, and potential therapeutic utility for Alzheimer disease. Free Radic Biol Med 2012;52:35-45

23. Fournier LR, Ryan-Borchers TA, Robison LM, et al. The effect of soy milk and isoflavone supplements on cognitive performance in healthy postmenopausal women. J Nutr Health Aging 2007;11:155-64. 